attending for routine $x$-ray investigations is a biased estimate of the true prevalence of the disease in the community, it seems unlikely that comparisons between towns will be affected by these biases. The towns with higher prevalences showed this in both sexes and at all ages. The higher prevalences did not depend on a higher level of clinical suspicion of Paget's disease by doctors referring patients for skeletal $x$-rays, because they were recorded in both skeletal radiographs and in radiographs taken during barium studies, intravenous pyelography, and other abdominal examinations (table II). A study of $x$-ray request forms in Southampton, Blackburn, and Bolton has shown that in patients with radiological evidence of Paget's disease this diagnosis is rarely stated on the form. Although the prevalence was higher among patients referred for skeletal $x$-ray examination, most of whom would presumably have had skeletal symptoms such as backache, standardisation to allow for the differing proportions of skeletal and other types of examination had little influence on the overall prevalence in each town (table II). The towns with higher prevalences showed this independently of the extent of the disease, as indicated by the number of bones affected (table III).

The findings suggest that the differences in radiological prevalence of Paget's disease recorded in this study reflect geographical differences in disease prevalence, the most striking feature of which is the high prevalence in the Lancashire towns. The two obvious characteristics of these Lancashire towns are that they are northern and industrialised. That the prevalence of Paget's disease does not depend on latitude alone is shown by the finding of a low prevalence in York (table I). That it is not only related to industrialisation is shown by the low prevalence in Stoke. It is hoped that further studies which are being carried out in northern industrial towns will elucidate this. In addition, studies of other Lancashire towns are being undertaken to determine the extent of the apparent focus of high prevalence.

We are most grateful to the radiologists for allowing us access to their departments and to the radiographers and $x$-ray records staff in the 14 towns. Without their kindness and help the survey would not have been possible. This study was funded by a grant from the Department of Health and Social Security.

Requests for reprints should be addressed to Dr D J P Barker, Community Medicine, South Block, General Hospital, Southampton SO9 4XY.

\section{References \\ Barker, D J P, and Gardner, M J, British fournal of Preventive and Social Medicine, 1974, 28, 226. \\ 2 Benn, R T, and Wood, P H N. Paper read to Society for Social Medicine at Rennes, 1972. \\ ${ }^{3}$ Barker, D J P, and White, G, unpublished. \\ 4 Guyer, P B, and Clough, P W L, unpublished. \\ ${ }^{5}$ Murray, R O, and Jacobson, H G, The Radiology of Skeletal Disorders, vol 1. Edinburgh and London, Churchill Livingstone, 1972. \\ ${ }^{6}$ Campbell-Golding, $\mathrm{F}$, in $A$ Textbook of $X$-ray Diagnosis, vol 6, ed S C Shanks and $P$ Kerley. London, Lewis, 1971. \\ ${ }^{7}$ Barry, H C, Paget's Disease of Bone. Edinburgh, Churchill Livingstone, 1969. \\ ${ }^{8}$ Pygott, F, Lancet, 1957, 1, 1170.}

(Accepted 3 March 1977)

\title{
Diagnosis of invasive candidosis by enzyme immunoassay of serum antigen
}

\author{
R C WARREN \\ A BARTLETT, \\ D E BIDWELL, \\ M D RICHARDSON, A VOLLER, \\ L O WHITE
}

British Medical fournal, 1977, 1, 1183-1185

\section{Summary}

Enzyme immunoassay was used to measure Candida albicans-related antigen in sera of rabbits and mice infected with $C$ albicans. A range of heterologous antigens tested gave no cross reactions. Of the three patients who were investigated and gave positive reactions, two were confirmed as having deep candida infections. Enzyme immunoassay is efficient, simple, and sensitive, and may prove valuable in the early diagnosis of invasive candida infections. Department of Microbiology, University of Birmingham, Birming-
ham B15 2TT

R C WARREN, PHD, research fellow

M D RICHARDSON, PHD, research fellow

L O WHITE, PHD, research fellow

Nuffield Institute of Comparative Medicine, Zoological Society of London, London NW1

A BARTLETT, PHD, research fellow

D E BIDWELL, PHD, research fellow

A VOLLER, DSC, MRCPATH, senior lecturer, London School of Hygiene and Tropical Medicine

\begin{abstract}
Introduction
Invasive fungal disease in immunosuppressed or otherwise compromised hosts has been encountered with increasing frequency in those who have undergone transplantation ${ }^{1}$ or open heart surgery ${ }^{2}$ and others. ${ }^{3}$ Diagnosis depends on detecting increasing titres of precipitating and agglutinating antibodies in patients' sera by Ouchterlony double diffusion, counterimmunoelectrophoresis (CIE), ${ }^{4}$ or enzyme immunoassay..$^{56}$ The more direct approach of detecting Candida albicans protein antigen in patients' sera has been made by crossed-line electrophoresis, ${ }^{\prime}$ and cell-wall mannan has been detected by passive haemagglutination. ${ }^{*}$

For routine testing of many serum samples, a method is still required that combines high sensitivity, using small volumes of serum, with unequivocal results at an early stage in the development of the disease. For these reasons we used the microplate double-antibody sandwich method of enzyme immunoassay, ${ }^{9}$ based on the concept of Engvall and Perlmann, ${ }^{10}$ for detecting circulating candida antigen.
\end{abstract}

\section{Methods}

Animal inoculations-Mice were injected subcutaneously with $5 \mathrm{mg}$ of cortisone (Cortistab) one day before intravenous challenge with $0.1 \mathrm{ml}$ of $10^{5}$ blastospores $/ \mathrm{ml}$ from a 12-hour culture of $C$ albicans strain 6224 (Mycological Reference Laboratory, London) suspended in distilled water. Groups of 10 mice were killed by cervical 
dislocation three, four, five, and six days after they had been infected. They were bled by cardiac puncture, and the resulting sera were pooled. Rabbits were inoculated intravenously with $10^{8}$ blastospores of $C$ albicans strain 19321 suspended in $1.0 \mathrm{ml}$ distilled water (clinical isolate from a case of candida vaginitis obtained from $\mathrm{Dr}$ R M Warren, Southampton Pathology Service). Rabbits were bled daily until death four days after infection.

Antisera-Antisera were raised in rabbits using antigens prepared by disrupting blastospores from a 48-hour culture of $C$ albicans (strain 6224) in a Braun homogeniser, as described by Evans et al. ${ }^{11}$ The homogenate was freeze dried, reconstituted in phosphate buffered saline (PBS) to a concentration of $20 \mathrm{mg}$ protein $/ \mathrm{ml}$, and $1-\mathrm{ml}$ aliquots were emulsified with equal quantities of Freund's incomplete adjuvant and injected intramuscularly at fortnightly intervals into two rabbits. When a strong precipitin response was detected by CIE $20 \mathrm{ml}$ of blood was withdrawn and serum prepared for enzyme immunoassay after mixing with convalescent serum from a rabbit challenged with $C$ albicans blastospores.

Enzyme immunoassay-The immunoglobulin fraction of rabbit antiserum to $C$ albicans antigen 6224 was precipitated with sodium sulphate and diluted to $100 \mu \mathrm{g}$ protein $/ \mathrm{ml}$, and $200-\mu \mathrm{l}$ aliquots were added to each well of polyvinyl microhaemagglutination plates (Cooke microtitre M29 AR, Dynatech Laboratories). After incubation for four hours at $37^{\circ}$ wells were washed three times in PBS ( $\mathrm{pH} \mathrm{7.4)}$ containing $0.05 \%$ Tween 20 . Excess fluid was shaken off, and the wells were filled with test sera diluted in PBS Tween and incubated for two hours at room temperature. The washing procedure was repeated before $200 \mu \mathrm{l}$ of enzyme conjugate (rabbit immunoglobulins to $C$ albicans conjugated to alkaline phosphatase (Sigma)), diluted 1/200 in PBS Tween, was added to each well. Plates were incubated overnight at $4^{\circ}$ and washed as before, and $200 \mu \mathrm{l}$ of enzyme substrate solution ( $1 \mathrm{~g} p$-nitrophenyl phosphate/l in $1-M$ diethanolamine buffer, $\mathrm{pH} 9 \cdot 8$ ) was added to each well. Enzyme substrate reactions were stopped by adding $50 \mu \mathrm{l}$ of 3-M sodium hydroxide when the absorbance at $405 \mathrm{~nm}$ of the reference antigen reached a predetermined value. Results were expressed as the optical density (OD) at $405 \mathrm{~nm}$.

$C I E$ - The method described by Mackenzie and Philpot ${ }^{12}$ was used, substituting only Litex LSA agarose (Litex, Glostrup, Denmark) for Lab $M$ agar.

Heterologous antigens-Other antigens tested for possible cross reactions with $C$ albicans were $(a)$ influenza, about $10^{10}$ particles $/ \mathrm{ml}$, (b) Aspergillus fumigatus culture filtrate, $(c)$ diptheria toxin, $(d)$ gonococcus cell smash, $(e)$ tetanus toxin, $(f)$ anthrax toxin, $(g)$ clostridium toxin ( $C$ welchii culture filtrate).

\section{Results}

ANIMAL STUDIES

Infected mice-Enzyme immunoassay using a serum dilution of $1 / 10$ gave OD readings indicative of the presence of $C$ albicans antigen at four, five, and six days after infection (table I). In contrast, CIE using neat serum gave positive results only at day 6 after infection.

Infected rabbit-No antigen was detected by CIE in rabbit sera collected 36 hours to four days after infection with $C$ albicans. On enzyme immunoassay antigen was first shown as early as 36 hours after infection (table II).

\section{HUMAN STUDIES}

Case 1-A 57-year-old man received a kidney transplant on 30 July 1975. In September 1975 he developed fever and oral thrush, which was treated with nystatin. After he died, on 29 September 1975,

TABLE I-Comparison of enzyme immunoassay with counter-immunoelectrophoresis in detecting $C$ albicans antigen in sera of cortisone-treated mice

\begin{tabular}{|c|c|c|c|c|c|}
\hline \multirow{2}{*}{$\begin{array}{c}\text { Serum } \\
\text { dilution }\end{array}$} & \multirow{2}{*}{$\begin{array}{l}\text { Uninfected } \\
\text { mice }\end{array}$} & \multicolumn{4}{|c|}{ Time after $C$ albicans infection } \\
\hline & & Day 3 & Day 4 & Day 5 & Day 6 \\
\hline \multicolumn{6}{|c|}{ Enzyme immunoassay (OD at $405 \mathrm{~nm}$ ) } \\
\hline $1 / 10$ & $0 \cdot 13$ & $0 \cdot 10$ & 0.31 & $0 \cdot 84$ & 0.62 \\
\hline \multicolumn{6}{|c|}{ Counterimmunoelectrophoresis } \\
\hline Neat & - & - & - & - & + \\
\hline
\end{tabular}

TABLE II-Detection of $C$ albicans-related antigen in infected rabbits by enzyme immunoassay (OD at $405 \mathrm{~nm}$ )

\begin{tabular}{|c|c|c|c|c|}
\hline & $\begin{array}{l}\text { Serum } \\
\text { dilution }\end{array}$ & $\begin{array}{l}\text { Incubation } \\
\text { buffer }\end{array}$ & $\begin{array}{l}\text { Uninfected } \\
\text { rabbit }\end{array}$ & $\begin{array}{l}\text { Value at time after } \\
C \text { albicans infection }\end{array}$ \\
\hline Rabbit A & $1 / 20$ & $0 \cdot 10$ & 0.06 & 0.21 (day 2) 0.47 (day 4) \\
\hline Rabbit B . & $1 / 10$ & $0 \cdot 18 \pm 0.02 *$ & $0.17 \pm 0.03^{*}$ & $\begin{array}{l}0.36 \pm 0.04^{*}(36 \mathrm{~h}) 0.88 \\
\pm 0.08^{*}(48 \mathrm{~h})\end{array}$ \\
\hline
\end{tabular}

*Values are means $\pm \mathrm{SD}$ for five readings.

TABLE III-Results of immunoassay (OD $405 \mathrm{~nm}$ ) of normal human sera from patients infected by $C$ albicans

\begin{tabular}{|c|c|c|c|c|}
\hline & $\begin{array}{c}\text { Serum } \\
\text { dilution }\end{array}$ & $\begin{array}{l}\text { Buffer } \\
\text { control }\end{array}$ & $\begin{array}{c}\text { Normal } \\
\text { sera (mean } \\
\text { of } 9 \text { values) }\end{array}$ & Values (on sample dates) \\
\hline Case $1 .$. & $1 / 2$ & $0 \cdot 10$ & 0.11 & $\begin{array}{c}0.19 \text { (31 Aug), } 0 \cdot 25 \text { (24 Sept), } 0 \cdot 29(25 \\
\text { Sept), 0.33(29 Sept) }\end{array}$ \\
\hline $\begin{array}{l}\text { Case } 2 . . \\
\text { Case } 3 . .\end{array}$ & $\begin{array}{l}1 / 10 \\
1 / 10\end{array}$ & $\begin{array}{l}0 \cdot 10 \\
0 \cdot 10\end{array}$ & $\begin{array}{l}0 \cdot 10 \\
0 \cdot 10\end{array}$ & $\begin{array}{l}0.41 \text { (19 Dec), } 0.46(20 \mathrm{Dec}) \\
0.68 \text { (16 Aug), } 0.81(17 \mathrm{Sept})\end{array}$ \\
\hline
\end{tabular}

massive candida infections of the oesophagus and lungs were discovered. Serum samples, taken four and five days before death and on the day of death, gave enzyme immunoassay results consistent with the presence of $C$ albicans antigen. All sera were negative for $C$ albicans antigen by CIE.

Case 2-A 25-year-old woman was admitted with polyarteritis nodosa in December 1975. She developed fever in mid-December 1975 and died on 20 December. At necropsy candida infection of the larynx and epiglottis was found, although this was not considered to be the cause of death. Enzyme immunoassay gave results consistent with the presence of candida antigen in the serum.

Case 3-A man, who had received a kidney transplant, developed a severe candida lung infection in September 1976. He recovered after treatment with flucytosine. Enzyme immunoassay of sera taken during the course of disease showed OD readings consistent with the presence of candida antigen.

\section{HETEROLOGOUS ANTIGENS}

A collection of high-titering antigens all gave negative results when tested by enzyme immunoassay for candida antigen (table IV).

TABLE IV-Antigens tested by enzyme immunoassay for possible cross reaction with $C$ albicans antisera

\begin{tabular}{|c|c|c|c|c|c|}
\hline & & OD & & & OD \\
\hline $\begin{array}{l}\text { Influenza ... } \\
\text { Clostridium toxin .. } \\
\text { Aspergillus fumigatus } \\
\text { Diphtheria toxin .. }\end{array}$ & $\begin{array}{l}\cdots \\
\cdots \\
\cdots\end{array}$ & $\begin{array}{l}0 \cdot 17 \\
0 \cdot 14 \\
0 \cdot 08 \\
0 \cdot 18\end{array}$ & $\begin{array}{l}\text { Anthrax toxin } \\
\text { Tetanus toxin } \\
\text { Gonococcus } \\
\text { C albicans... }\end{array}$ & $\begin{array}{l}\cdots \\
\cdots \\
\cdots\end{array}$ & $\begin{array}{l}0.10 \\
0.13 \\
0.09 \\
1.82\end{array}$ \\
\hline
\end{tabular}

\section{Discussion}

Enzyme immunoassay showed the presence of $C$ albicansrelated antigen in the sera of infected mice before it could be detected by CIE (table 1) and in infected rabbits when CIE failed to detect antigen at any stage. The two tests took similar times to carry out, but the immunoassay was more adaptable to large-scale use, and it was possible to use very small quantities of dilute serum.

Of the three patients who were shown to be positive for candida antigen by enzyme immunoassay, two were later shown to have severe infections, although the candida infection in the third patient (case 2) might have been more important than the necropsy findings suggested.

The efficiency, simplicity, and sensitivity of enzyme immunoassay for detecting antigen suggest that the method may be 
used in the early diagnosis of invasive candida infections. The same type of procedure is also extremely promising for detecting other pathogens such as viruses. ${ }^{13} 14$ Enzyme immunoassay will probably find a place in the early diagnosis of invasive aspergillosis, which is currently being investigated.

RCW was supported by an MRC retraining award and thanks Professor H Smith and Dr D W R Mackenzie for encouragement.

\section{References}

${ }^{1}$ Bach, M C, et al, Transplantation Proceedings, 1973, 5, 549.

${ }^{2}$ Rubenstein, E, et al, Medicine, 1975, 54, 331.

${ }^{3}$ Baker, B D, Human Infections with Fungi, Actinomycetes and Algae. Berlin, Springer-Verlag, 1971.
4 Dee, T H, and Rytel, M W, fournal of Laboratory and Clinical Medicine, $1975,85,161$.

5 Hommel, M, Truong, T K, and Bidwell, D E, La Nouvelle Presse Médicale, 1976, 5, 2789.

6 Voller, A, Bidwell, D E, and Bartlett, A, Protides of the Biological Fluids, 1976, 24, 751 .

7 Axelsen, N H, and Kirkpatrick, C H, fournal of Immunological Methods, $1973,2,245$.

8 Weiner, M H, and Yount, W J, fournal of Clinical Investigation, 1976, 58, 1045.

9 Voller, A, Bidwell, D E, and Bartlett, A, Bulletin of the World Health Organisation, 1976, 53, 55.

${ }^{10}$ Engvall, E, and Perlmann, P, Immunochemistry, 1971, 8, 871.

11 Evans, E G V, et al, British Medical fournal, 1973, 4, 86.

12 Mackenzie, D W R, and Philpot, C M, Mycopathologia, 1975, 57, 1.

13 Wolters, G, et al, fournal of Clinical Pathology, 1976, 29, 873.

14 Voller, A, et al, fournal of General Virology, 1976, 33, 165.

(Accepted 3 March 1977)

\title{
Continuous-flow plasmapheresis in management of severe rhesus disease
}

\author{
J GRAHAM-POLE, W BARR, M L N WILLOUGHBY
}

British Medical fournal, 1977, 1, 1185-1188

\section{Summary}

Eight patients with severe rhesus disease and expected fetal loss were treated by intensive plasmapheresis using a continuous-flow cell separator. Plasmapheresis was started at 16-27 weeks' gestation, and continued until planned intrauterine transfusion or until the infant was delivered or the rhesus disease became uncontrolled again. Altogether 24 to 2371 of plasma was exchanged over periods ranging from seven to 16 weeks. In seven of the eight patients the anti-D concentration fell during the period of plasmapheresis. Amniotic fluid spectrophotometry values remained below those recorded in the preceding pregnancy in six out of seven women. In five patients an attempt was made to control the rhesus disease by plasmapheresis alone, and two of these women delivered infants who survived. In the other three cases the infants died, one from the idiopathic respiratory distress syndrome and the other two in utero.

These preliminary findings suggest that intensive plasmapheresis with a cell separator may reduce fetal haemolysis and in some cases can sustain this effect until the infant is delivered. Nevertheless, plasmapheresis may best be used to reduce haemolysis until intrauterine transfusions may be given more safely after 30 weeks' gestation.

\section{Introduction}

Continuous-flow cell separators permit plasmapheresis of up to 71 two or three times a week and offer a possible means of

\footnotetext{
Departments of Haematology, Obstetrics, and Child Health, University of Glasgow, Yorkhill, Glasgow G12 8SJ

J GRAHAM-POLE, MRCP, lecturer in child health (now senior lecturer in paediatric oncology, St Bartholomew's Hospital, London EC1A 7BE) W BARR, FRCS, FRCOG, consultant obstetrician

M L N WILLOUGHBY, MD, MRCPATH, consultant haematologist
}

controlling severe rhesus disease. We have used this approach in eight patients with exceptionally severe rhesus isoimmunisation and have tried to answer the following questions: (1) Can circulating maternal anti-D be removed faster than it reaccumulates? (2) Is such removal accompanied by a decrease in fetal haemolysis, as judged by amniotic fluid spectrophotometry? (3) Can intensive plasmapheresis without intrauterine transfusion save affected infants when the mother has had previous rhesus stillbirths?

\section{Patients and methods}

Obstetric and serological details of the patients are shown in tables I and II. The decision to start plasmapheresis was made when the combination of these factors, usually supported by the findings on early amniocentesis spectrophotometry, suggested that the fetus was unlikely to survive with conventional management. Only highly motivated mothers were accepted, and the procedure was fully explained.

Maternal antibody level-To estimate rhesus antibodies we measured both the indirect antiglobulin (Coombs) titre assay and the anti-D immunoglobulin concentration. ${ }^{1}$ The latter is more reliable than antibody titration ${ }^{2}$ and generally correlates with the severity of haemolysis. ${ }^{3}$ All but one of our mothers had levels of IgG higher than $4 \cdot 0 \mathrm{mg} / \mathrm{l}$, mostly much higher, which by itself suggested the presence of severe rhesus disease. ${ }^{4}$

Amniocentesis findings-All except the first patient (case 1) underwent amniotic fluid spectrophotometry performed by the Liley method ${ }^{5}$ before treatment. Though no definite predictions can be made before 25 weeks' gestation, optical density (OD) measured at a wavelength $(\Delta)$ of $450 \mathrm{~nm}$ is probably the best index of severity and is essential to monitor progress. All eight had levels above 0.1 OD unit, five having levels of at least 0.2 OD unit when first measured, which is equivalent to the IUT zone at 34 weeks' gestation.

Plasmapheresis procedure-Plasmapheresis was carried out using an Aminco Cell Separator (American Instrument Company, Maryland). ${ }^{6}$ Volumes ranging from 2.5 to 7.01 of plasma were exchanged for reconstituted freeze-dried plasma or plasma protein fraction. Fresh frozen plasma $(500 \mathrm{ml})$ was given after the latter to replace clotting factors. Heparin to a total dose of about 10000 units was used as anticoagulant, and calcium gluconate $(10 \mathrm{ml} 10 \%)$ was always given at the start and often during the procedure. ${ }^{7}$ Blood samples were taken before and after the procedure. A full blood count, 12 microanalyses (using the SMA/12 Microanalyser ${ }^{8}$ ), and bacteriological culture were performed, 